\title{
Prevalence of Hospital
}

\section{Functional Impairment in a}

Colombian Elderly Population

at the San Ignacio University

Hospital

\author{
Prevalencia de deterioro funcional hospitalario \\ en una población colombiana de ancianos en el \\ Hospital Universitario San Ignacio
}

Prevalência de deterioro funcional hospitalar em uma população colombiana de idosos no Hospital Universitário San Ignacio

Sandra Milena Castelblanco Toro, $\mathrm{MD}^{1 *}$

Ana María Suárez Acosta, MD ${ }^{1}$

Damaris Sánchez Plazas, MD $^{1}$

David José Coca León, MD ${ }^{1}$

Diego Andrés Chavarro-Carvajal, MD, MSc, $\mathrm{PhD}^{1}$

Received: 8 de abril de 2019 - Accepted: 24 de julio de 2019

Doi: http://dx.doi.org/10.12804/revistas.urosario.edu.co/revsalud/a.8354

To quote this article: Castelblanco Toro SM, Suárez Acosta AM, Sánchez Plazas D, Coca León DJ, Chavarro-Carvajal DA. Prevalence of Hospital Functional Impairment in a Colombian Elderly Population at the San Ignacio University Hospital. Rev Cienc Salud. 2019;17(3):20-30. Doi: http://dx.doi.org/10.12804/revistas.urosario.edu.co/revsalud/a.8354

\section{Abstract}

Introduction: Functional decline following hospitalization ( $\mathrm{FDH})$ is defined as the loss of the functional capacity to perform at least one basic activity of daily life (BADL) when being discharged from hospital; a situation compared to functional capacity performed in the last couple of weeks, prior the acute disease. This impairment is precipitated in the elderly by factors such as aging, architectural conditions, malnutrition, hospital routines and physical restraints. The objective of this study is determining the prevalence of functional impairment in adults over 65 years of age hospitalized in the San Ignacio University Hospital (siuн) and its associated factors. Materials and Methods: A descriptive cross-sectional study of a hospital cohort was carried out from December $1^{\text {st }} 2015$ to December $31^{\text {st }} 2017$. Univariate and multivariate analyses were performed to identify associated variables. Results: 1055 people were included,

1 Instituto de Envejecimiento de la Facultad de Medicina de la Pontificia Universidad Javeriana, Unidad de Geriatría del Hospital Universitario San Ignacio.

Autor de correspondencia: samicastelblanco@hotmail.com 
with FDH prevalence of $41.14 \%$. The three main factors associated with the development of FDH in the elderly population that consulted the siun were time of hospital stay [oR 1.88, CI95\% (1.41-2.49), $p=<0.0001$ ], malnutrition [or 1.59, CI95\% (1.16-2.19), $p=0.004$ ] and delirium [or 2.38, CI95 \% (1.83-3.10), $p=<0.001$ ]. Conclusion: FDH is a highly prevalent condition in the geriatric population hospitalized in the San Ignacio University Hospital, where length of stay, malnutrition and delirium are the factors associated with its disease onset.

Keywords: Geriatric assessment, elderly, hospitalization, activities of daily living.

\section{Resumen}

Introducción: el deterioro funcional hospitalario (DFH) se define como la pérdida de la capacidad para realizar al menos una actividad básica de la vida diaria (ABVD) en el momento del alta respecto a la situación funcional dos semanas previas al inicio de la enfermedad aguda; dicha situación es precipitada en los ancianos por factores como el envejecimiento, las condiciones arquitectónicas, la desnutrición, las rutinas hospitalarias y las restricciones físicas. El presente estudio busca determinar la prevalencia de deterioro funcional en adultos mayores de 65 años hospitalizados en el Hospital Universitario San Ignacio (Husi) y sus factores asociados. Materiales y métodos: se realizó un estudio descriptivo de corte transversal de una cohorte hospitalaria de diciembre de 2015 al 31 de diciembre de 2017; se llevó a cabo un análisis univariado y multivariado para identificar variables asociadas. Resultados: se incluyeron 1055 personas, con una prevalencia de DFH del 41,14\%. Los tres principales factores asociados al desarrollo de DFH en la población anciana que consulta al husi fueron tiempo de estancia hospitalaria [oR 1,88, CI95\% (1,41-2,49), $p=<0,0001$ ], malnutrición [oR 1,59, CI95\% (1,16-2,19), $p=0,004$ ] y delirium [or 2,38, CI95\% (1,83-3,10), $p=<0,001]$. Conclusión: el DFH es una condición altamente prevalente en la población geriátrica hospitalizada en el Hospital Universitario San Ignacio, siendo el tiempo de estancia intrahospitalaria, la malnutrición y el delirium factores asociados a su aparición.

Palabras clave: evaluación geriátrica, anciano, hospitalización, actividades cotidianas.

\section{Resumo}

Introdução: o deterioro funcional hospitalar define-se como a perda da capacidade para realizar pelo menos uma atividade básica da vida diária (ABVD) no momento da alta médica respeito à situação funcional duas semanas prévias ao início da doença aguda. Dita situação e precipitada nos idosos por fatores como o envelhecimento, as condições arquitetônicas, a subnutrição, rutinas hospitalares e restrições físicas. O presente estudo busca determinar a prevalência de deterioro funcional em idosos de 65 anos hospitalizados no Hospital Universitário San Ignacio (нusi) e seus fatores associados. Materiais e métodos: se realizou um estudo descritivo de corte transversal de uma coorte hospitalar de dezembro de 2015 ao 31 de dezembro de 2017; se realizou uma análise univariada e multivariada para identificar variáveis associadas. Resultados: se incluíram 1055 pessoas, com uma prevalência de DFH do 41,14\%. Os três principais fatores associados ao desenvolvimento de DFH na população idosa que consulta ao Husi foram tempo de permanência hospitalar [or 1,88, CI95\% (1,41-2,49), $p=<0,0001$ ], a subnutrição [oR 1,59, CI95\% $(1,16-2,19), p=0,004]$ e o delirium [or 2,38, CI95\% (1,83-3,10), $p=<0,001]$. Conclusão: o DFH é uma condição altamente prevalente na população geriátrica hospitalizada no Hospital Universitário San Ignacio sendo o tempo de permanência intra-hospitalar, a subnutrição e o delirium fatores associados à sua aparição.

Palavras-chave: avaliação geriátrica, idoso, hospitalização, atividades cotidianas. 


\section{Introduction}

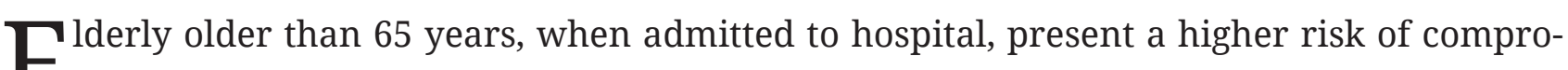
-mising functionality during hospital stay and after hospital discharge (1). An acute disease or an exacerbated chronic disease, changes produced by aging, and the negative aspects occurring during the hospitalization of an elderly patient precipitate the loss of functional ability (2). Factors such as reduction of mobility, polypharmacy, inadequate architectural conditions, malnutrition, hospital routines and physical restraints contribute to developing this diagnosis $(3,4)$. As a consequence, functional dependence leads to a higher risk of hospital readmissions, admission to geriatric homes and increase of mortality $(5,6)$.

Hospital functional impairment (HFI) is defined as the loss of the ability to perform at least one basic activity of daily life (BADL) (eating, bathing or showering, using the toilet, dressing, sphincter continence, getting out of bed or of a chair, walking, and climbing stairs) at the moment of hospital discharge, concerning the baseline (considered as two weeks before the onset of the acute disease), corresponding in the Barthel Index to the decline of $10 \%$ of scoring related to the population basal functionality level, or the loss of ten points in the scale (7-9).

Lendínez and cols. reported that functional impairment reaches a proportion of $32.2 \%$ in elderly older than 65 years, and it grows up to $63.3 \%$ in elderly older than 85 years (10). In Spain, the reported HFI ranges between 35 and $70 \%$ in patients older than 60 years; patients older than 70 years showed impairment in some BADL by $46 \%$, while in people older than 90 years this figure reaches $88 \%$ (9). In Colombia, there are no studies characterizing HFI in elderly population admitted in elderly care units, given the hospital conditions and the lack of care units that would document this impairment.

The objective of this study is to determine prevalence of hospital functional impairment, and the associated factors, in patients older than 65 years hospitalized in the San Ignacio University Hospital in the period between December $1^{\text {st }} 2015$ and December $31^{\text {st }} 2017$, and the associated factors.

\section{Materials and Methods}

descriptive cross-sectional study of a hospital cohort, between December $1^{\text {st }} 2015$ and $31^{\text {st }}$ 2017 was carried out, reviewing the medical records. This review included the records of elderly persons older than 65 years, hospitalized in the geriatric service of the San Ignacio University Hospital, who were admitted for medical pathology. They underwent functional measurement using the Barthel scale for documenting baseline (two weeks prior to hospital admission) and discharge from hospital. Patients hospitalized for psychiatric and chirurgical pathologies, with uncomplete information in the database, as well as patients 
who died during the hospital stay, those who have requested a voluntary discharge against medical advice during hospitalization, or those who were referred to another institution were excluded.

Data obtained from the medical records review were fed into a database built according to the considered variables. Dependent variable was HFI, as independent variables sociodemographic characteristics were included: age, as continuous variable; gender (male, female); polypharmacy, considered in dichotomous form, defined as consumption of five or more medications; comorbidities, identified as a continuous variable according to their identification at hospitalization; readmission, measured as a dichotomous variable if the patient had or had not been readmitted; social risk, defined at the admission, whether an adequate support network for the patient was or was not identified; hospital complication, determined as a dichotomous variable according to whether there was a complication or not; malnutrition at admission, defined using a mini nutritional assessment (MNA) as in risk of malnutrition or in malnutrition; delirium, at admission, defined as the existence of at least two out of four criteria of the Confusion Assessment Method (CAM); dementia, indicated as the presence of dementia as clinical diagnosis; duration of hospital stay (DHs), considered according to the number of days, as a continuous variable; and mobility during the stay.

The sample size was calculated based on the proportion formula, obtaining a required minimum sample size of 566 patients of lower risk (around 0.1), which corresponded to a population of low and medium risk. The required sample size for population of high risk (risk of circa 0.3) was 242 patients.

A descriptive analysis was performed with information of the variables of interest using measures of central tendency and dispersion. Additionally, mean and interquartile range were used, according to criteria of normal and not normal distribution. Categorical variables were expressed in frequency tables.

In the bivariate analysis, significance level or $p$ value $(p=<0.05)$ was implemented. Regarding association measures, the Chi-squared test was implemented for the dichotomous variables; and for the continuous variables the Mann-Whitney U test, for establishing whether there were statistically significant differences. Finally, regarding the logistic regressions, a binary model and a multiple model were used adjusted by the confusion variables. In the latter model, age and gender were considered confusion variables. Odds ratio (oR) obtained, together with trust intervals of $95 \%$ (CI of $95 \%$ ), were reported. Analysis was conducted with the Stata 14 program (statistical software package for descriptive analysis).

The study is considered to pose no risk in the terms of Resolution 8430 of Colombian law. The protocol was approved by the Research and Ethics Committee of the siuH and the Xaverian University. 


\section{Results}

Erom December $1^{\text {st }} 2015$ until December 31 2017 , information was gathered of 1055 older 1 adults, with a mean age of 85.58 years old (IRQ 9), percentage of participation of women reached 56.68\%; the mean Barthel index prior to admission was 59.97. Out of the total studied population, 124 (11.75\%) had been readmitted; 822 (72.91\%) had a diagnosis of dementia; 797 (75.54\%) presented malnutrition; 469 (44.45\%) were admitted with delirium; polypharmacy was present in $36.11 \%$ of the studied patients, and 892 (84.54\%) were at social risk. Additionally, the average number of comorbidities was 4.8. It was found that 434 persons (41.14\%) presented hospital functional impairment (HFI). Patients' demographic data are shown in table 1.

Table 1. Characteristics of patients hospitalized at the siuH in the geriatric service

\begin{tabular}{cc}
\hline Variable & $\begin{array}{c}\text { N (\%) or Mean } \\
\text { (IQR) }\end{array}$ \\
\hline Male & $449(42.55)$ \\
Female & $606(57.45)$ \\
Age (Mean, IQR) & $85.58(6.33)$ \\
Time of Hospital Stay & $4.5(4)$ \\
(Mean, IQR) & 59.97 \\
Barthel at Admission & $745(71.4)$ \\
Barthel <90 & $4.88(3)$ \\
Number of Comorbidities & $124(11.75)$ \\
(Mean, IQR) & $822(77.91)$ \\
Readmission & $797(75.54)$ \\
Dementia & $892(84.54)$ \\
Malnutrition & $93(8.81)$ \\
Social Risk & $469(44.45)$ \\
In-Hospital Complications & $381(36.11)$ \\
Delirium & $443(41.99)$ \\
\hline Polypharmacy at Admission & \\
Immobility during Hospital Stay & \\
\hline IQR = Interquartile Range & \\
$\mathrm{n}=1055$ &
\end{tabular}

Data of the bivariate analysis is summarized in table 2, where the analysis is divided into two groups: patients with HFI and those who did not present HFI. Population presenting HFI was predominantly female (54.14\%); mean age was 87 years (IQR $8, p=0.071$ ). At admission, $42.97 \%$ showed Barthel scores of 20 points (IQR 50, $p=0.00$ ), with poorest scores regarding those who did not present functional impairment. $52.79 \%$ with DFH presented dementia, versus $47.2 \%$ who showed 
no impairment ( $p=0.046) ; 54.6 \%$ presented delirium compared with $45.4 \%$ not presenting HFI $(p=0.00)$. As for the presence of malnutrition, findings showed that, of the patients with HFI, the number of individuals suffering malnutrition at admission was higher than those in the group with no HFI ( $439=55.1 \%$ v. $358=44.9 \%, p=<0.000)$.

In terms of social risk, in the HFI group 368 patients had a poor support network; while 524 patients of the group with no HFI showed this condition $(41.3 \%$ and $58.7 \% ; p=0.855$, respectively). Regarding time of hospital stay, a mean of five days stay (IQR 3) was established in individuals with HFI, while those with no HFI had a mean stay of four days (IQR $4 ; p=<0.004$ ). On the other hand, findings showed that 45 patients with HFI presented some complication, while 48 patients with no HFi showed in-hospital complications (51.61\% v. $48.39 \%$; $p=0.032$ ).

Table 2. Bivariate analysis of individuals with HFI V. individuals with no HFI

\begin{tabular}{cccc}
\hline Variable & $\begin{array}{c}\text { With No Functional } \\
\text { Impairment } \\
\mathbf{n}=\mathbf{6 2 1}\end{array}$ & $\begin{array}{c}\text { With Functional } \\
\text { Impairment } \\
\mathbf{N}=\mathbf{4 3 4}\end{array}$ & $\boldsymbol{p}$ Value \\
Male & $250(55.68 \%)$ & $199(44.32 \%)$ & 0.071 \\
Female & $371(61.22 \%)$ & $235(38.78 \%)$ & 0.071 \\
Age (Mean, IQR) & $87(8)$ & $86(9)$ & 0.062 \\
Time of Hospital Stay & $4(4)$ & $5(3)$ & $0.000^{*}$ \\
(Mean, IQR) & & & \\
Barthel at Admission & $65(50)$ & $60(55)$ & 0.228 \\
(Mean, IQR) & $430(57.03)$ & $324(42.97)$ & 0.055 \\
Barthel $<90$ & $70(50)$ & $20(50)$ & $0.000^{*}$ \\
Barthel at Discharge & & $5(3)$ & 0.332 \\
(Mean, IQR) & $4(3)$ & $47(37.9 \%)$ & 0.436 \\
Number of Comorbidities & $77(62.1 \%)$ & $434(52.79 \%)$ & $0.046^{*}$ \\
(Mean, IQR) & $438(47.2 \%)$ & $39(55.1 \%)$ & $0.00^{*}$ \\
Readmission & $358(44.9 \%)$ & $368(41.3 \%)$ & 0.855 \\
Dementia & $524(58.7 \%)$ & $45(48.39 \%)$ & $0.032^{*}$ \\
Malnutrition & $48(51.61 \%)$ & $256(54.6 \%)$ & $0.00^{*}$ \\
Social Risk & $213(45.4 \%)$ & $154(40.4 \%)$ & 0.707 \\
In-Hospital Complication & $227(59.6 \%)$ & $157(35.4 \%)$ & $0.001^{*}$ \\
Delirium & $286(64.6 \%)$ &
\end{tabular}

${ }^{*} \mathrm{p}=<0.05 ; \mathrm{IQR}=$ Interquartile Range

For dichotomous variables the chi-square test was implemented, and for the continuous variables the Mann Whitney U Test. $n=1055$

The logistic regression binary model found a statistically significant relation between HFI and age [or 0.97, CI95 \% (0.95-0.999), $p=0.021$ ]; male gender [or 1.25, CI95 \% (0.98-1.60), $p=0.071$ ]; time of hospital stay greater than seven days [or 1.08, CI95 \% (1.05-1.18), $p=0.0001$; malnutrition [or 1.96, CI95\% (1.44-2.66), $p=0.0001$ ]; dementia [or 1.30, CI95 \% (1.004-1.68), 
$p=0.046$ ]; in-hospital complication [or 1.59, CI95\% (1.03-2.43), $p=0.033$ ]; delirium [or 2.75, CI95 \% (2.13-3.54), $p=0.0001$ ]; and immobility during the stay [or 1.50, CI95 \% (1.17-1.93), $p$ $=0.0001]$.

As it can be observed in Table 3, in the multivariate analysis all variables were adjusted by age and sex, resulting in a statistically significant association of HFI and time of hospital stay lower than seven days [or 1.88, CI95\% (1.41-2.49), $p=0.0001$ ]; malnutrition [or 1.59, CI95 \% (1.16-2.19), $p=0.0001$ ], and delirium [or 2.38, CI95\% (1.83-3.10), $p=0.001$ ].

Table 3. Multivariate Analysis

\begin{tabular}{ccccc}
\hline Variable & $\begin{array}{c}\text { Raw oR } \\
(\text { CI95 } \%)\end{array}$ & $\boldsymbol{p}$ Value & $\begin{array}{c}\text { Adjusted oR } \\
\text { (CI95\%) }\end{array}$ & $\boldsymbol{p}$ Value \\
\hline THS > D Days & $2.25(1.71-2.95)$ & $0.000^{*}$ & $1.88(1.41-2.49)$ & $0.000^{*}$ \\
Malnutrition & $1.96(1.44-2.66)$ & $0.000^{*}$ & $1.59(1.16-2.19)$ & $0.004^{*}$ \\
Delirium & $2.75(2.13-3.54)$ & $0.000^{*}$ & $2.38(1.83-3.10)$ & $0.000^{*}$ \\
\hline
\end{tabular}

${ }^{*} \mathrm{p}=<0.05 ; \mathrm{OR}=$ Odds Ratio; $\mathrm{CI}=$ Confidence Interval

\section{Discussion}

Changes in functionality of patients at the time of hospitalization follow complex trajectories and, as a consequence, severe secondary complications arise (11-15). The present study showed that, of the 1055 patients included in the analysis, 434 persons presented HFI, corresponding to $41.14 \%$, a similar figure to those produced by studies performed in elderly population, with prevalence figures between 30\% and 67\% (1264\% women, 24\% nonwhite (12-17).

Comparatively, Mañas and cols. conducted a study entitled "Deterioro de la capacidad funcional en pacientes ancianos egresados de un servicio de medicina interna" ("Impairment of Functional Ability in Elderly Patients Admitted in a Service of Internal Medicine”) in a Colombian population and reported that the functional loss percentage obtained of the sample was $17.3 \%$, although the results are not comparable, since the included population, the design and the methodology were different (17). In contrast, the study of Cares and cols., performed in Chile, with population of similar characteristics and variables, found that $72 \%$ of population presented loss of some functional ability during hospital stay (18).

Predictors of hospital functional decline have been described before in patients at high HFI, associated with a higher burden of disease in terms of large hospital outcomes $(19,20)$. A bivariate analysis was performed comparing patients with HFI and those not presenting this condition. Loss of one or more basic activities of daily life during hospitalization occurred predominantly in the population with longer hospitalization time; this may largely be due 
to hospital dynamics and to the severity of the index disease. Additionally, the impact of malnutrition considerably increases morbimortality and time of hospital stay (11). In the assessed population, it was documented that malnutrition was prevalent both in those who developed HFI, and in those who did not, with a prevalence of $55.1 \%$ and $44.9 \%$, respectively.

$44.45 \%$ of the included patients presented delirium at admission, where a significatively higher proportion of them was present in those with HFI, in relation to patients who did not decline functionally (55.1\% v. $44.9 \%$ ), this fact is connected to dementia prevalence in the studied population (77.91\%). Likewise, the average number of diseases in both patients groups reached 4.88; the comorbidity mean difference was not statistically significant. Polypharmacy was present in a higher proportion of patients with no HFI versus those with HFI (59.6\% v. $40.4 \%$ ), a trend also evidenced in immobility during hospital stay; it was more prevalent in the population that did not develop HFI (64.6\% v. $35.4 \%)$, a finding that contrasts with the study of De Saint Hubert and cols., "Factores de riesgo que predicen un deterioro funcional posterior en pacientes ancianos hospitalizados" ("Risk Factors that Predict a Ulterior Functional Decline in Elderly Patients”), in which one of the main risk factors for HFI was the low mobility in hospital stay (19).

Age is a continuously mentioned factor among factors related to development of HFI, in our study we found that the population that presented most frequently functional decline was population older than 80 years, explained by aging changes, pluripathology, high frequency of dementia, and polypharmacy $(21,22)$.

Regarding the logistic regression, we found that, in the raw analysis, with statistically significant differences, there was a greater association of HFI to age; male gender, with an OR of 1.25; and time of hospital stay greater than seven days, with an on of 1.08. Malnutrition increased the HFI by 1.9 times, as well as hospital complications with or of 1.59; and delirium, with an or of 2.75. In line with the results, multiple studies have concluded that the common predictors for developing HFI include age, delirium, extended hospital stay, and other cognitive deficits (21). Additionally, in the logistic regression, with variables adjusted by gender and age, statistical significance was found in the appearance of HFI by a time of hospital stay greater than seven days, with an or of 1.88; malnutrition, with an or of 1.9; and delirium, with an or of .38.

These findings are significant in the context of the Colombian elderly population, since the performed analyses had not been considered before in geriatric care units in Colombia $(17,23)$. With this in mind, it is necessary to early identify these conditions in patients, with the purpose of carrying out preventive actions that contribute to reduce the functional decline in our patients.

In the study, a direct measure of cognitive, functional and nutritional factors was performed with standardized measures with the best validity $(2,9,17)$. Inclusion and exclusion criteria were clearly defined, thus reducing the risk of statistical bias. Relevant confounding 
factors identified by reviewing previous studies were considered, as well as a multivariate adjustment with the purpose of determining factors associated with developing HFI (24); for this reason, further studies are required for assessing interventions proposed for preventing HFI in our population in order to determine which interventions were effective.

Limitations of this study were connected with the fact that performing the assessment of the patient's baseline conditions was carried out in the emergency room. For this reason, it is possible that baseline information that consider the early functionality decline associated with acute disease was collected, however, this method could be consistent with previous studies of patients admitted in emergency departments. There were no direct comorbidity measures as possible confounding factors.

\section{References}

1. Cornette P, Swine C, Malhomme B, Gillet J-B, Meert P, D'Hoore W. Early evaluation of the risk of functional decline following hospitalization of older patients: development of a predictive tool. Eur J Public Health. 2006;16(2):203-8.

2. Chavarro-Carvajal DA. Deterioro funcional hospitalario. Revisión y actualización con una perspectiva orientada a mejorar la calidad de atención del anciano. Univ Med. 2017;58(3):1-6. Doi: 10.11144/Javeriana.umed58-3.dfhr

3. Osuna-Pozo CM, Ortiz-Alonso J, Vidán M, Ferreira G, Serra-Rexach JA. Revisión sobre el deterioro funcional en el anciano asociado al ingreso por enfermedad aguda. Rev Esp Geriatr Gerontol. 2014;49(2):77-89. Doi: 10.1016/j.regg.2013.08.001

4. Morton C. Creditor. Hazards of hospitalization of the elderly. Ann Intern Med. 1993;118(3):219-23.

5. Sleiman I, Rozzini R, Barbisoni P, Morandi A, Ricci A, Giordano A, et al. Functional trajectories during hospitalization: a prognostic sign for elderly patients. Gerontol A Biol Sci Med Sci. 2009;64(6):659-63.

6. Tinetti ME, Williams C. Falls, injuries due to falls, and trhe risk of admisson to a nursing home. N Engl J Med. 1997;337:1279-84.

7. Brown CJ, Foley KT, Lowman JD, MacLennan PA, Razjouyan J, Najafi B, et al. Comparison of posthospitalization function and community mobility in hospital mobility program and usual care patients a randomized clinical trial. JAMA Intern Med. 2016;176(7):921-7. Doi: 10.1001/jamainternmed.2016.1870

8. Hoogerduijn JG, Buurman BM, Korevaar JC, Grobbee DE, De Rooij SE, Schuurmans MJ. The prediction of functional decline in older hospitalised patients. Age Ageing. 2012;41(3):381-7. Doi: 10.1093/ageing/afs015

9. Vidán Astiz MT, Sánchez García E, Alonso Armesto M, Montero Errasquin B, Martínez de la Casa A, Javier Ortiz F, et al. Deterioro funcional durante la hospitalización en ancianos. Beneficios del ingreso en el servicio de geriatría. Rev Esp Geriatr Gerontol. 2008;43(3):133-8. 
10. Cruz Lendínez AJ, Pancorbo Hidalgo PL, García Fernández FP, Carrascosa García MI, Jiménez Díaz MC, Villar Dávila R. Deterioro funcional en ancianos ingresados en un hospital sin unidades geriátricas. Gerokomos. 2010;21(1):8-16.

11. Mudge AM, O’Rourke P, Denaro CP. Timing and risk factors for functional changes associated with medical hospitalization in older patients. Gerontol A Biol Sci Med Sci. 2010;65A(8):866-72. Doi: 10.1093/gerona/glq069

12. Covinsky KE, Palmer RM, Fortinsky RH, Counsell SR, Stewart AL, Kresevic D, et al. Loss of independence in activities of daily living in older adults hospitalized with medical illnesses: increased vulnerability with age. J Am Geriatr Soc. 2003;51(4):451-8.

13. Ostir GV, Berges IM, Kuo YF, Goodwin JS, Fisher SR, Guralnik JM. Mobility activity and its value as a prognostic indicator of survival in hospitalized older adults. J Am Geriatr Soc. 2013;61(4):551-7. Doi: 10.1111/jgs.12170

14. Barnes DE, Mehta KM, Boscardin WJ, Fortinsky RH, Palmer RM, Kirby KA, et al. Prediction of recovery, dependence or death in elders who become disabled during hospitalization. J Gen Intern Med. 2013;28(2):261-8.

15. Kortebein P, Symons TB, Ferrando A, Paddon-Jones D, Ronsen O, Protas E, et al. Functional impact of 10 days of bed rest in healthy older adults. J Gerontol A Biol Sci Med Sci. 2008;63(10):1076-81.

16. Fortinsky RH, Covinsky KE, Palmer RM, Landefeld CS. Effects of functional status changes before and during hospitalization on nursing home admission of older adults. J Gerontol A Biol Sci Med Sci. Med Sci. 1999;54(5):521-6.

17. Mañas MD, Marchán E, Conde C, Sánchez S, Sánchez-Maroto T, Molina MC. Deterioro de la capacidad funcional en pacientes ancianos ingresados en un servicio de medicina interna. An Med Interna. 2005;22:34-6.

18. Cares Lay V, Dominguez CC, Fernandez MJ, Farias CR, Chang GWT, Fasce G, et al. Evolución de la capacidad funcional en adultos mayores hospitalizados en la unidad geriátrica de agudos del hospital clínico de la Universidad de Chile. Rev Med Chil. 2013;141(4):419-27.

19. De Saint-Hubert M, Schoevaerdts D, Poulain G, Cornette P, Swine C. Risk factors predicting later functional decline in older hospitalized patients. Acta Clin Belg. 2009;64(3):187-94.

20. Portegijs E, Buurman BM, Essink-Bot ML, Zwinderman AH, de Rooij SE. Failure to regain function at 3 months after acute hospital admission predicts institutionalization within 12 months in older patients. J Am Med Dir Assoc. 2012;13(6):569.e1e7. Doi: 10.1016/j. jamda.2012.04.003

21. McCusker J, Kakuma R, Abrahamowicz M. Predictors of functional decline in hospitalized elderly patients: a systematic review. J Gerontol A Biol Sci Med Sci. 2002;57(9):569-77. Doi: 10.1093/gerona/57.9.M569

22. García CN, Esteban DS. Deterioro funcional del anciano tras un ingreso hospitalario. Rev Enferm. 2009;(2009)1:20-5.

23. Baztán JJ, Suárez-García FM, López-Arrieta J, Rodríguez-Mañas L. Eficiencia de las unidades geriátricas de agudos: metaanálisis de estudios controlados. Rev Esp Geriatr Gerontol. 2011;46(4):186-92. 
Prevalence of Hospital Functional Impairment in a Colombian Elderly Population at the San Ignacio

24. Delgado Parada E, Suárez García FM, Miñana Climent JC, Medina García A, López Gaona V, Gutiérrez Vara S, et al. Variables asociadas a deterioro funcional al alta y a los 3 meses en ancianos hospitalizados por insuficiencia cardíaca. Rev Esp Geriatr Gerontol. 2009;44(2):66-72. 